\title{
GAZDASÁGI, TÁRSADALMI ÉS EGYÉNI ÉRTÉKTEREMTÉS A FELSŐOKTATÁSBAN ${ }^{1}$
}

\author{
KIRÁLY GÁBOR* - GÉRING ZSUZSANNA \\ Felsőoktatás Jövője Kiválósági Központ, Budapesti Gazdasági Egyetem
}

A felsőoktatási intézményeknek mind hazai, mind nemzetközi téren sok különböző érintetti csoport igényeinek kell megfelelniük. Ezek a különböző elvárások más-más társadalmi szerephez és felelősséghez kapcsolódnak. Írásunkban három ilyen kihívást emelünk ki, és mutatjuk be a rájuk adott domináns válaszokat. Egyrészt röviden bemutatjuk a vállalkozó egyetem koncepcióját, mint a gazdasági érték képzésének motorját. Másrészt a foglalkoztathatóság - egyéni értékteremtés - kérdéskörével kapcsolatban tárgyaljuk a képzéshez és fejlesztéshez kötődő kihívásokat és az ezekre adott válaszokat. Harmadrészt a társadalmi értékteremtés témáját érintve bemutatjuk a bevonással kapcsolatos törekvéseket, ezen belül is a nyitott tudomány megközelítését. Mindezek felvetik a kérdést, hogy milyen intézményi keret lenne a legalkalmasabb ilyen sokszínü célrendszer kezelésére. Véleményünk szerint - és különösen a hazai felsőoktatási intézmények számára - nemcsak a homogenitás, azaz a meglévő példák és formák átvétele és követése lehet a járható út, hanem a heterogenitásban rejlő lehetőségek kiaknázása, azaz a sajátosságok megkeresése, valamint az egyedi, a lokális környezetbe illeszkedő, de nemzetközileg is életképes modellek kialakítása.

Kulcsszavak: felsőoktatás jövője, vállalkozó egyetem, képzés és fejlesztés, nyitott tudomány, felsőoktatási intézmények beágyazottsága

Higher education institutions (HEIs) need to respond to the expectations of several stakeholders both in national and international arenas. These expectations can be related to several different social roles and responsibilities. This paper highlights three different challenges of and dominant responses from HEIs. Firstly, we discuss the concept of the entrepreneurial university as a main driver of economic value creation. Secondly, in relation to the issue of human value creation, namely, the issue of employability, we touch upon the challenges of teaching and development and identify answers HEIs attempt to give to these. Thirdly, we give a brief account on the initiatives of social engagement and open science. All these aspects raise the question of what kind of organisational framework would be most applicable to meet these diverse and complex requirements. Accord-

\footnotetext{
* Levelező szerző: Király Gábor, Budapesti Gazdasági Egyetem, 1055 Budapest, Markó u. 29-31. E-mail: kiraly.gabor@uni-bge.hu

1 A tanulmány az NKFIH által támogatott, „Az üzleti képzés jövője” (FK 127972) elnevezésű projekt keretében készült.
} 
ing to our argument, striving for institutional homogeneity, in other words, the adaptation of existing examples and forms is only one path among many. Heterogeneity can also be a feasible option - especially for Hungarian HEIs - that is, finding idiosyncratic characteristics and elaborating organisational forms embedded in the local contexts yet being viable in an international arena.

Keywords: future of higher education, entrepreneurial university, teaching and development, open science, embeddedness of higher education institutions

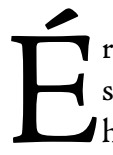
rdekes megnézni, hogy napjainkban milyen üzeneteket fogalmaznak meg a felsőoktatási intézmények. Ha átfutjuk a felsőoktatási hírleveleket, akkor azt láthatjuk, hogy az intézmények újfajta módon próbálnak kapcsolódni az őket körülvevő társadalmi kontextushoz. Úgy tűnik, hogy az egyetemek ${ }^{2}$ egyre inkább érzik a bizonyítás terhét azzal kapcsolatban, hogy hogyan és milyen mértékben járulnak hozzá a társadalomhoz. Ehhez vagy a meglévő szerepeiket értelmezik újra, vagy új társadalmi feladatokat vállalnak fel. Ugyanakkor a felsőoktatás újrapozicionálásának igénye egyben azt is mutatja, hogy már nem magától értetődő, hogy a felsőoktatási intézmények és az általuk ellátott feladatok társadalmi értéket képviselnének. A felsőoktatási intézményeknek tehát egyre inkább foglalkozniuk kell a szervezeti legitimációjukkal (Gumport 2000), azaz erőfeszítéseket kell tenniük, hogy létezésük értelmét igazolni tudják más szereplők számára.

A legitimációs kényszerrel kapcsolatos viták gyakran jelennek meg mind az akadémiai, mind a nemzetközi szakpolitikai diskurzusban. Az egyik terület, amely a probléma lényegét érinti, a felsőoktatás fö küldetésének, missziójának a témája (Laredo 2007; Pinheiro-Langa-Pausits 2015b). Az ezzel kapcsolatos gondolkodás azokat a különböző feladatokat és felelősségeket próbálja meg meghatározni, amelyeket a felsőoktatásnak ennek a célnak az érdekében fel kellene vállalnia. Ugyanakkor azt is érdemes figyelembe venni, hogy ezek a (lehetséges) feladatok és felelősségek általában nem önmagukban állnak, hanem viszonylag jól meghatározható érintetti körökhöz tartoznak.

Például a kormányzatok számos országban növekvő nyomást gyakorolnak a felsőoktatási intézményekre a finanszírozási kérdésekben, nevesen, hogy diverzifikálják a bevételi forrásaikat és pénzügyi értelemben egyre inkább önfenntartóvá váljanak (ShinKim 2014). A gazdasági szereplők azt várják az intézményekben folyó kutatások eredményeitől, hogy azok jól kapcsolódjanak a gazdasági problémákhoz, cél- és alkalmazásorientáltak legyenek, valamint támogassák vagy akár katalizálják a piaci innovációkat. A foglalkoztathatóság pedig a hallgatók (és a szüleik) számára vált az utóbbi évtizedekben központi kérdéssé. Szintén kérdés, hogy mi a felsőoktatási intézmények társadalmi szerepe egy folyamatosan változó társadalmi és technológiai környezetben (KirályGéring 2019). Ezek a nemrégiben megfogalmazott és/vagy újra felbukkanó külső igények olyan legitimációs válság eredményei, amelyek nem csupán egy-egy szereplőt és nem is

Tisztában vagyunk azzal, hogy számos felsőoktatási intézmény létezik, mégis, az olvashatóság kedvéért, ebben az írásban ezt a két kifejezést (felsőoktatási intézmény, egyetem) szinonimaként használjuk. 
egy-egy régiót érintenek, hanem nemzetközi szinten az egész felsőoktatási szektort lépéskényszerbe hozzák.

A felsőoktatási intézmények különböző módon reagálnak erre a legitimációs válságra. Ehhez kapcsolódóan három olyan kihívásterületet azonosítottunk, amelyek a szervezeteket nehézségek és választások elé állítják. Egyrészt megvizsgáljuk, hogy az egyetemek lehetséges gazdasági szerepével kapcsolatban milyen elvárások fogalmazódnak meg a vállalkozó egyetem koncepciója keretében. Másodikként áttekintjük, hogy az egyetemek mennyire és hogyan képesek az emberi értékteremtéshez, szükebb értelemben a hallgatók foglalkoztathatóságához hozzájárulni. Végül a társadalmi értékteremtéssel kapcsolatban felmerül annak a kérdése is, hogy az intézmények mennyire képesek megtartani, esetleg kiterjeszteni azt a szerepüket, hogy hozzájáruljanak a társadalmi szintű változásokhoz, valamint tematizálják a társadalmak önértelmezésével kapcsolatos diskurzusokat. A tanulmány ennek a három fő területnek a tárgyalása mentén halad tovább.

\section{A felsőoktatás mint a gazdasági értékteremtés terepe $\mathrm{e}^{3}$}

Az egyetemek gazdaságra gyakorolt tényleges és potenciális hatása nem számít új témának a felsőoktatással foglalkozó akadémiai és szakpolitikai irodalomban. Az az elképzelés azonban, hogy a felsőoktatási intézmények működésének alapjaiban kell megváltozni, hogy be tudjanak kapcsolódni az innovációs folyamatokba és ezáltal közvetlenül hozzájáruljanak a gazdasági növekedéshez és versenyképességhez, viszonylag új. Az ezzel kapcsolatos elvárások legjobban a vállalkozó egyetem koncepciójában állnak össze egy többé-kevésbé koherens rendszerré.

A vállalkozó egyetem elképzelése először az USA-ban jelent meg az 1980-as, '90-es években (Etzkowitz 1988; Clark 1998). Ezt követően viszonylag gyorsan a felsőoktatási intézmények egyik legmeghatározóbb globális szervezeti sablonjává vált (PinheiroStensaker 2014). Az eredeti elképzelés azon a feltételezésen alapul, hogy az akadémiai, ipari és kormányzati szférák között nagyobb átfedésre van szükség, azaz a tudástermelés hármas spirál modelljére (triple helix model) érdemes törekedni (Leydesdorff-Etzkowitz 1996).

Ebben az értelmezésben a hagyományos egyetemeknek, amelyeket eddig a társadalmi-gazdasági kontextusuktól külön álló, viszonylagosan jól definiált feladatkörökkel rendelkező entitásként kezeltünk, nyitottabb, külső kapcsolatokra és lehetőségekre érzékeny szervezetekké kellene válniuk. Ez azt is jelentené, hogy kevésbé függenének az államtól érkező forrásoktól és diverzifikálnák a bevételeiket azáltal, hogy más gazdasági vagy állami szereplők számára kínálnak szolgáltatásokat, valamint értékesítik a munkatársaik által termelt tudást és az általuk kifejlesztett technológiákat (Andeßner-Greiling 2017). A szervezeti átalakulás ezen aspektusa kifejezetten hangsúlyosan jelenik meg a nemzeti és nemzetközi szakpolitikai diskurzusban. Ennek az érvelésnek a megerősödése nem meglepő módon egybevág azzal a trenddel, hogy az állami hozzájárulás mértéke folyamatosan csökken, és az egyetemek abban a helyzetben találják magukat, hogy több mindent kellene elérniük kevesebb forrás felhasználásával (Shin-Kim 2014).

A vállalkozó egyetem témáját, az ezzel kapcsolatos érveket, ellenérveket és gyakorlati kihívásokat bővebben tárgyalja Király (2019) tanulmánya. Ez a rész bár tematikailag kapcsolódik az említett tanulmányhoz, de gondolatmenetében és érvelésében eltér attól. 
$\mathrm{A} z$ érvelés szerint ahhoz, hogy szervezeti szinten is vállalkozóvá válhassanak, az egyetemek „központi magját”, azaz a menedzsment funkcióit kell megerősíteni (Clark 1998). Bár általában ezt kevésbé hangsúlyozzák, a menedzsment erősödése együtt jár az akadémiai közösség önszerveződési és önrendelkezési képességeinek gyengülésével (Docherty 2011). Ezzel párhuzamosan az is jellemző, hogy a felsőoktatási intézményeket a „szervezeti központból” egyre inkább a piaci logika szerint próbálják működtetni. A napi szintű müködésben olyan elveknek (hatékonyság, termelékenység) az érvényesítése jelenik meg, amelyet korábban rendszeridegennek, az egyetemi szemlélettel és léttel összeegyeztettethetetlennek tekintettünk volna (Slaughter-Rhoades 2004; Kováts 2011).

Ez az új szervezeti sablon együtt jár a tudástermeléssel, kutatással kapcsolatos megváltozott felfogással is. Ez a felfogás úgy tekint a kutatásra, mint az innováció, a növekedés és a versenyképesség fö hajtóerejére (Marginson 2014). Ennek eredményeképpen azokat a tudásformákat részesíti előnyben, amelyek kereskedelmi potenciállal rendelkeznek, miközben leértékel más területeket, amelyek ebben a keretrendszerben nem számítanak értékteremtőnek és produktívnak. Ebben az újraértékelési folyamatban tehát az emberi tudás kiterjedt területei válhatnak kegyvesztetté és látszólag feleslegessé.

A vállalkozó egyetem elképzelése gyakran jelenik meg úgy, mint az egyetlen lehetséges vagy legalábbis a legadekvátabb válasz a felsőoktatási intézmények problémáira. Eszerint azért van szükség arra, hogy különböző ösztönzők segítségével elmozdítsuk a felsőoktatási intézményeket ebbe az irányba, hogy megmentsük őket saját maguktól, befelé forduló természetüktől, intellektuális belterjességüktől. Gyakori érvelés, hogy az egyetemek nem lehetnek külön álló szigetek, hanem központi szerepet kell vállalniuk az őket körülvevő vállalkozói ökoszisztémában (Guerrero et al. 2016).

Ezzel szemben megjelennek azok a vélemények is, amelyek a vállalkozó egyetem koncepciójában nem a szervezet kiterjesztésének, fejlődésének lehetőségét látják, hanem pont az egyetem társadalmi szerepének leszúkítését egyetlen dimenzióra. Az egyetemeken ugyanis minden korban központi fontosságú volt a jó élet kérdéseiről szóló vita és gondolkodás. Ezeknek a kérdéseknek a tisztázása feltételez egyfajta távolságot a mindennapi létfenntartás kényszereitől, valamint a külső politikai és gazdasági szereplők hatásaitól. Szintén megemlíthetjük az egyetemek szerepét a társadalom általános (nem csupán vagy nem is elsősorban gazdasági értelemben vett) fejlődésében és a társadalmi mobilitási csatornák biztosításában. A tágabb társadalmi értékteremtésre vonatkozó funkciók elvesztése ebben az értelemben az egyetemi tér elszegényedéseként jelenik meg (Ibarra-Colado 2007).

Mások szerint a vállalkozó egyetem kialakítására tett lépések az egyetemi szféra autonómiája elleni támadássorozat részei, amely komoly károkat okoz akár a felelős, független értelmiségi lét ethoszának, akár az egyetemi elit újratermelődésének a szempontjából (Shore 2010).

Ahogy fent már említésre került, ebben az új viszonyrendszerben a társadalom- és bölcsészettudományok elveszítik korábbi pozícióikat. A piaci logikában nem tudnak eléggé hatékonyak, produktívak lenni, valamint képtelenek megfelelő mértékben hozzájárulni a gazdasági versenyképességhez és növekedéshez. Ugyanakkor azt is érdemes megjegyezni, hogy hagyományosan ezek voltak azok a területek, amelyeknek az volt a szerepük, hogy alternatív szervezeti és társadalmi valóságokat kidolgozzanak (Wright 2011). Ezen alternatív jövőképeknek egyrészt az a céljuk, hogy az aktuális jelen társadal- 
mi kritikájaként szolgáljanak, másrészt pedig az, hogy mások számára is hozzáférhető és inspiráló jövőképeket adjanak. Egy kritikusabb szempontból azt is mondhatjuk, hogy a vállalkozó egyetem elképzelése inkább a reménytelenséget erősíti fel az egyetemi térben (Amsler-Facer 2017). Haszontalanként beállítani a kritikai társadalmi gondolkodás területeit még inkább marginalizálhatja az egyetemi értelmiséget a felsőoktatás jövőjének vitájában. A sikeres szervezeti változásnak ugyanakkor még egy tisztán menedzsmentorientált perspektívából nézve is előfeltétele, hogy a folyamatban a fó felsőoktatási funkciók napi szintű működtetéséért és fejlesztéséért felelős egyetemi dolgozók érvei, gondolkodása és tapasztalatai is megjelenjenek (Géring et al. 2018).

Azt is érdemes kiemelni, hogy nemcsak a vállalkozói értékteremtésnek (Fuller et al. 2010), hanem a vállalkozó egyetemnek is többféle felfogása lehet. Scharmer és Käufer (2000) például kiemelik, hogy a közös jelentésalkotás, a közösen osztott jövőkép és a kölcsönös tanulás előfeltételei egy olyan egyetemi környezetnek, ahol a vállalkozók kialakulhatnak. Az egyetemi vállalkozók helyett, akik az értékesítésre koncentrálnak, vállalkozói szemléletü egyetemi oktatók dolgozhatnak együtt hallgatókkal olyan projekteken, amelyek kisebb vagy egyes esetekben egészen kiterjedt pozitív társadalmi változásokat képesek generálni. Ez a kiindulópont a vállalkozási szemlélet egy emberközelibb változatát képviseli és ezáltal el is távolodik az akadémiai kapitalizmus kizárólagosan piacorientált logikájától.

Hasonlóképpen, Shumar és Robinson érvelése szerint a hallgatók és az egyetemi dolgozók nem csak egyetlen módon válhatnak vállalkozóvá, hiszen a felsőoktatásban a vállalkozói megközelítés nemcsak az üzleti és gazdasági témákkal hozható kapcsolatba, hanem társadalmi ügyekkel is, mint például a fenntarthatóság, az emberi jogok, a társadalmi egyenlőség (Shumar-Robinson 2018).

Érdemes megemlíteni, hogy a vállalkozó egyetemnek ez az emberibb, egyben szélesebb értelmezése kevésbé kizáró abban a tekintetben, hogy számos eltérő tudományterületről (beszéljünk akár irodalomtudományról, filozófiáról, matematikáról vagy kémiáról) feltételezi, hogy vállalkozói szemlélettel képesek értéket teremteni külső érintettek számára. Természetesen nem az a cél, hogy minden hallgatóból vállalkozó váljon, hanem hogy vállalkozói szemléletet és készségeket sajátítsanak el (Krueger 2015), hogy aztán ezeket a későbbi munkájuk során használni tudják (Lackéus 2015). Ez elvezet az általunk meghatározott második területhez.

\section{A felsőoktatás mint az emberi értékteremtés terepe}

A foglalkoztathatóság egy másik alapkérdés a felsőoktatás jövője szempontjából. A felsőoktatási intézmények felé - azon túl, hogy azt várják el tőlük, hogy járuljanak hozzá a gazdasági növekedéshez és versenyképességhez - leginkább az az elvárás fogalmazódik meg, hogy a tanulóikat készítsék fel az életre, de ezen belül is a munka világára. Más szavakkal: ne csupán a gazdasági, hanem az emberi értékteremtés folyamatában is vegyenek részt. Ugyanakkor úgy tűnik, hogy a tudásátadás „hagyományos” módszerei nem müködnek már annyira jól, mint eddig (Davidson 2017).

Shin (2014a) szerint ennek az az egyik oka, hogy a felsőoktatási intézmények már a tömegesedés utáni (post-massified) állapotban vannak. Ez azt is jelenti, hogy a hallgatók többen vannak, sokfélébbek, és általában tanulmányi szempontból kevésbé felkészültek, mint korábban (Shin 2014b). Emiatt számos oktató bizonytalanodott el abban a tekin- 
tetben, hogy hogyan is kellene oktatni. Úgy tünik a vizsgálatokból, hogy az egyszerű és már kipróbált tudásátadási technikák - mint például az előadások és az oktatók által előre megszabott olvasmánylisták - már nem elegendőek ahhoz, hogy a hallgatók tudása és képességei ténylegesen fejlődjenek a felsőoktatási tanulmányaik során (Arum-Roksa 2011). Ez egyben azt is jelenti, hogy már egyre kevésbé elég, ha az oktatók csak átadják az általuk fontosnak vélt tudás „tartalmát” a hallgatóknak. Képesnek kell lenniük arra is, hogy megragadják, és ami talán még nehezebb, meg is tartsák a tanulók figyelmét, nem is beszélve arról, hogy képesek legyenek elősegíteni, támogató „állványokkal” (scaffolding) keretezni, valamint személyesre szabni a tanulás folyamatát (Ormrod 2017).

Ehhez kapcsolódik az is, hogy a tanulói populáció és az oktatói szerep változásain túl, az oktatás technológiai környezete is folyamatosan alakul. A hagyományos környezetet - kis iróniával - a „csirkeetetési modellel” írhatjuk le. Ebben a helyzetben egy személynél (vagy gazdánál) volt minden tudás (kukoricás vödör), a tanulók (csirkék) lelkesen köré gyűltek és kellőképpen hálásak voltak minden megkapott információ- és tudásmorzsáért (kukoricáért) (Jeffries-Andrews 2014). Ebben az „információhiányos” környezetben a tudáshoz és a tartalmakhoz való hozzáférés kulcskérdéseknek számítottak. Ehhez képest egy olyan kontextus felé mozdultunk el, ahol számos más lehetséges forrás mellett az oktató már csupán az egyike a lehetséges „tartalomszolgáltatóknak”. Ráadásul a tanulók állandóan maguknál hordanak olyan hordozható infokommunikációs eszközöket (mobiltelefon, tablet, laptop stb.), amelyeken szó szerint egy gombnyomással érnek el külső tartalmakat.

Többek között ennek a két aspektusnak (kevésbé felkészült tanulók egy információgazdag környezetben) a kölcsönhatásai is szükségessé teszik az elmozdulást a frontális oktatási eszközöktől. Feltételezhetjük, hogy a 21-ik századi felsőoktatás számára nem az lesz a dilemma, hogy mit tudunk a hallgatóknak megtanítani a folyamatosan változó tudástartalmakból. Sokkal inkább az a fó kérdés, hogy hogyan találunk új utakat, módszereket, folyamatokat, amelyekkel a tudás megértésével (új információk kognitív feldolgozása), megítélésével (források hitelességének felmérése) és kombinálásával (tudományos igényességű értelmezések kialakítása) kapcsolatos készségeiket tudjuk fejleszteni (Shin 2014b). Tehát kevésbé a felsőoktatási intézmények által létrehozott és átadott tartalmakra kerül a hangsúly, mint inkább arra, hogy a hallgatókat hogyan tudjuk felkészíteni arra, hogy utánanézzenek, kiválasszák, értelmezzék és rendszerezzék a hozzáférhető tudástartalmakat, sőt akár új tudást hozzanak létre (Aoun 2017; Hammershøj 2019).

Mindazonáltal felvetődik a kérdés, hogy mit is tekintünk eredményes tanulási környezetnek. Decuypere, Simons és Masschelein több tanulmányukban is arra hívják fel a figyelmet, hogy a domináns szakpolitikai diskurzus túlságosan is leszűkítő és leegyszerűsítő ebben a tekintetben (Decuypere-Simons-Masschelein 2011). Érvelésük szerint a „hivatalos”, tanulással kapcsolatos beszédmód úgy írja le a tanulást, mint egy viszonylagosan egyszerü és egyirányú folyamatot, amelyet nem csupán fel lehet, de fel is kell gyorsítanunk (Masschelein-Simons 2015). Emögött a gyorsulási kényszer mögött pedig az az elvárás áll, hogy hatékony dolgozókat képezzünk a munkaerőpiac számára olyan gyorsan és hatékonyan, ahogy csak lehetséges. Ez a szemlélet leginkább az üzemszerü állattartáshoz hasonlítható (hogy visszatérjünk a csirkeetetés metaforánkhoz), amely során egy meghatározott mennyiségű anyagot le kell gyűrni a célzott személyek torkán (legyenek akár hallgatók, akár baromfik), hogy minél gyorsabban használni tudjuk őket gazdasági célokra. 
Ezzel szemben a tanulás egy alternatív felfogása azt emeli ki, hogy ez a folyamat sokkal sokrétübb, összetettebb és kiszámíthatatlanabb, mint azt a szakpolitikai diskurzus sugallja. Ahelyett, hogy előre kidolgozott sablonokat és univerzálisan mindenkire alkalmazható válaszokat próbálnánk egymástól elszigetelt, ugyanakkor egymással versengő egyéneknek adni, a mély és maradandó tanulás azt feltételezi, hogy nehéz és bonyolult kérdéseket fogalmazunk meg és járunk együtt körbe a közösségünk jelenlegi és jövőbeli helyzetével kapcsolatban (Simons-Masschelein 2009). Némileg ellentmondásos módon ez a fajta, nehézkesebbnek és körülményesebbnek tűnő tanulási folyamat még „hatékonyabb" is lehet. Abban az értelemben lehet hatásosabb, hogy pont azokat az emberi minőségeket fejleszti, amelyekre a jövőben a tanulóknak szükségük lehet a társadalmi életükben, a munkahelyeiken, valamint a magánéletükben (Selingo 2018).

A $z$ oktatás és ezen belül a felsőoktatás legélesebb és legkíméletlenebb bírálatát az utóbbi években Caplan amerikai közgazdász írta meg The Case Against Education ( $\mathrm{Az}$ álláspont az oktatás ellen) címü könyvében (Caplan 2018). Szerinte az oktatási rendszer jelentős részét feleslegesen tartjuk fent. A képzési struktúrákban a tantárgyak elemzésével bemutatja, hogy minden oktatási szinten jelentős az aránya azoknak a tárgyaknak, amelyekre a tanulóknak semmi szükségük nem lesz a későbbi szakmai és magánéletükben. Ráadásul az egyik területről, helyzetről a másikra való tudás és/vagy képesség átvitele (transfer) csak nagyon korlátozottan, vagy legtöbb esetben egyáltalán nem történik meg. Caplan (2018) szerint azért tartunk fenn mégis ilyen költséges intézményeket, mert a végzettség - föleg az egyetemi diploma - erős jelzőfunkcióval bír.

Bár valószínűleg egy rosszabbul sikerült kurzus után az oktatók jelentős százaléka részben vagy teljes egészében egyetértene Caplan helyzetelemzésével, jelenleg is számos izgalmas kísérlet zajlik az oktatási, tanulási folyamatok újragondolására (Davidson 2017). A felsőoktatás újratervezésére tett erőfeszítések együtt járnak a tanulás kérdésének - már fent ismertetett - előtérbe kerülésével. Az egyik legérdekesebb kezdeményezés ebből a szempontból az amerikai Minerva Egyetem, ahol az oktatási, tanulási folyamatokat kifejezetten a tanulással kapcsolatos tudományos kutatások, eredmények figyelembevételével alakították ki. Ez már eleve rámutat a hagyományos felsőoktatási intézmények egyik legnagyobb tehetetlenségi tényezőjére, vagyis arra, hogy leginkább azt és úgy tanítanak, ahogy és amit az oktatóik szívesen csinálnak. Ebben az értelemben az oktatási portfólió, amit kínálnak, erősen kínálat- és nem keresletorientált (Selingo 2016). A Minerva online, de valós időben zajló szemináriumai elsősorban a tanulók részvételére, hozzászólásaira épülnek és csak kisebb mértékben az oktatók tudásmegosztására (Kosslyn-Nelson-Kerrey 2017). A részvételhez szükséges tudást a tanulók még a szemináriumok előtt, jellemzően egyedül sajátítják el online anyagok segítségével. A szemináriumok után az oktatók egyénenként részletes visszajelzést adnak a tanulók érvelésével, hozzászólásaival kapcsolatban. Ez a részvételre, gyakori visszajelzésekre és egyéni felelősségvállalásra épülő pedagógia-rendszer azonban még más lényeges elemekben is eltér a „hagyományos” képzési struktúrától. Egyrészt a tanulók folyamatosan mentális szokásokat gyakorolnak (például a korreláció és az okság megkülönböztetése), amelyek számos anyagrésznél reflektálnak újra és újra. Másrészt vannak átfogó elvek, amelyek a tanulmányaikban ismétlődően felbukkannak - ilyen például a rendszerszemlélet -, és amelyek a tanulók a biológiai, társadalmi és informatikai tanulásánál egyaránt lényeges szerepet játszanak (Kosslyn-Nelson-Kerrey 2017). E két utóbbi pedagógiai gyakorlat segít a felejtés és az átvitel (transzfer) problémájának kezelésében, valamint 
abban, hogy az elsajátított tudástartalmak között kiterjedt kognitív hálózat jöjjön létre (Ormrod 2017).

\section{A felsőoktatás mint a társadalmi értékteremtés terepe}

A felsőoktatás társadalmi értékteremtésben betöltött szerepe különösen fontos, hiszen a szektor komoly szereplő lehet a jövő társadalmainak alakításában. A fentiekben tárgyalt két aspektus leginkább az ismeretlen és bizonytalan jövőhöz való alkalmazkodási kihívásokra kínál válaszokat a belső átalakulás és a fő célok újraértelmezése révén (Barnett 2012). Ugyanakkor a társadalmi értékek vetülete azt a kérdést emeli a fókuszba, hogy miként tudják a felsőoktatási intézmények formálni a jövő társadalmait és hogyan tudnak közvetlenül vagy közvetetten hozzájárulni pozitív társadalmi változásokhoz. Ilyen közvetett hatást lehet elérni például a társadalmilag és gazdaságilag aktív hallgatók képzésével, hiszen ezek a hallgatók mind a saját életüknek, mind mások körülményeinek javítására tudják fordítani a megszerzett tudást és képességeket. Ez nem egy elhanyagolható befolyás, ennek ellenére a felsőoktatási intézmények ennél közvetlenebbül is hozzá tudnak járulni társadalmi értékek teremtéséhez - ami egyre inkább elvárásként is fogalmazódik meg velük szemben.

Ezt a szerepet gyakran a kissé homályos „harmadik misszió” fogalommal azonosítják. Meg kell azonban jegyeznünk, hogy ez a fogalmi tér átfed a vállalkozó egyetem körüli diskurzussal, amit fentebb részleteztünk. Ennek megfelelően manapság a harmadik misszióhoz kapcsolt kezdeményezések és programok legtöbbször a mérhető és összehasonlítható indikátorokban (mint például a bejegyzett szabványok száma, egyetemiipari közös projektek, spin-off-ok száma) való előrelépést célozzák, és ezért leginkább gazdasági és értékesítési célokhoz kapcsolódnak. A más típusú akadémiai bevonódást támogató kezdeményezések tipikusan önkéntes alapon és csak „nyomokban” találhatók meg az intézményekben, informális csatornákon keresztül szerveződve (Loi-Di Guardo 2015). Éppen ezért egyrészt legtöbbször nem is igazán tudnak túlnőni a személyes elköteleződés és az „akadémiai hobbik” szintjén. Másrészt sok esetben az egyetemi dolgozók nem is nagyon engedhetik meg maguknak, hogy ezekkel a kezdeményezésekkel foglalkozzanak, mert így is túlzottan leterheltek az oktatási és kutatási feladataikkal (Pinheiro-Langa-Pausits 2015b).

Találni azonban olyan érveket is, hogy a harmadik misszióhoz kapcsolódó tevékenységeket nem lenne szabad elkülöníteni és leválasztott szervezeti egységekbe koncentrálni (mint amilyenek például a technológiatranszfer irodák), hanem a társadalmi értékteremtésnek az egész intézményi gyakorlatot, és akár magát az intézményi felépítést is, át kéne hatnia (Pinheiro-Langa-Pausits 2015a). Ez a gondolatmenet pedig elvezet az úgynevezett „nyitott tudomány” (open science) kérdésköréhez.

Többek szemében a nyitott tudomány irány a harmadik misszió fogalmához képest jövőorientáltabb, hiszen megkérdőjelezi a hagyományos tudástermelési és tudásátadási gyakorlatokat azáltal, hogy általánosságban, az egész tudományhoz való hozzáférésre fókuszál (Fecher-Friesike 2014). Ilyen értelemben a megközelítés alapvetően kutatásorientált és a szervezeti „nyitást” a tudományos folyamatok számos szintjén szorgalmazza. Ezek a tudás-termelési folyamatokhoz való hozzáférés, azaz más szavakkal a kutatási folyamat maga; a létrejött tudás elérhetősége, vagyis a kutatási eredmények; valamint a részvételre és együttműködésre épülő kutatások lehetősége. 
Az utóbbi esetében a hozzáférés a hétköznapi emberek explicit bevonását jelenti, azaz nem szakértők részvételét a kutatási folyamatban. Ennek a mélysége és formája nagyon változatos lehet. A „mély” végén a skálának található a közösségi tudomány (citizen science), azaz azok a kezdeményezések, amelyek a laikusokat mint potenciális kutatótársakat vonják be a kutatásba (Catlin-Groves 2012).

A hozzáférés egy másik szintje a kutatások forrásainak és eredményeinek az elérhetőségéhez kötődik, nevesen a nyílt hozzáférésű adatokhoz és publikációkhoz. A fő érv emögött a kezdeményezés mögött, hogy a legtöbb akadémiai kutatás államilag - tehát az adófizetők pénzéből - finanszírozott, tehát az eredményeiket is meg kellene osztani az adófizetőkkel, azaz a tágabb értelemben vett nyilvánosággal (Cribb-Sari 2010). Ez azonban felveti a kérdést, hogy azok, akik nem rendelkeznek a kutatókhoz hasonló tudományos képzettséggel az adott területen, hogyan tudják megérteni és használni ezeket az adatokat és eredményeket. Ez pedig elvezet minket a tudományos kommunikáció hozzáférhetőségének dilemmájához, azaz a technikai hozzáférhetőségen túl a közérthetőség kérdésköréhez (Cribb-Sari 2010).

A legtöbb társadalomban a felsőoktatási intézmények már elvesztették a tudományos tudás elöállításának monopóliumát, hiszen napjainkban sok különböző helyen zajlik tudástermelés, gondolhatunk például a magánkutatóintézetekre, a vállalatokra, az agytrösztökre (think tanks), újságokra, portálokra stb. Ennek nyomán valós veszélye van annak, hogy nem feltétlenül a legpontosabb, érvényes és tudományosan alátámasztott eredmények formálják a nyilvános közbeszédet vagy az egyéni véleményeket, hanem azok, amelyek a legérthetőbb és legközvetlenebb formában kerülnek megfogalmazásra. Ezért az akadémiai kutatóknak (is) módot kell találniuk arra, hogy tudományos tényekre épülö „történeteket” és szövegeket hozzanak létre (Gee 2013). Azaz arra van szükség, hogy lefordítsuk a tudományos eredményeket „használható” tudássá és elmesélt, narratív formában hozzáférhető igazságokká.

\section{A felsőoktatási szektor jövője: homogenitás vagy heterogenitás?}

Mindezek felvetik a kérdést, hogy ha ilyen sokféle és akár ellentmondó elvárás létezik a különböző területeken, akkor milyen szervezeti forma tudna ezekre a legjobban válaszolni? Jelenleg két befolyásos szervezeti modell található globális szinten: a jól ismert élharcos, a kutató egyetem modellje és kihívója, a vállalkozó egyetem elképzelés. ${ }^{4}$

A korábbiakban részletesen bemutattuk a vállalkozó egyetem megközelítést, amelyre sokan a huszonegyedik századi felsőoktatás számos problémájának megoldásaként tekintenek. Hiszen azáltal, hogy szinergiát teremt a fó egyetemi missziók között a harmadik misszióba integrálva azokat, és emellett még bevételt is generál az innovatív felsőoktatási intézményeknek (Etzkowitz et al.2000), a vállalkozó egyetem elképzelés igazán vonzó a nemzetközi és hazai szakpolitika számára. Ugyanis egy vállalkozói szemléletü felsőoktatási intézmény nemcsak az állami költségvetésből igényel kevesebbet, de hozzá is tud járulni a regionális és nemzeti gazdasági növekedéshez és versenyképességhez. Ez az elképzelés valóban nagyon biztató - elméletileg. Ugyanakkor meglehetősen naiv is

\footnotetext{
4 Természetesen vannak egyéb modellek és próbálkozások is (lásd jelen számban Kováts Gergely írását a szövetkezeti egyetemekről), ugyanakkor véleményünk szerint ez a két szervezeti felépítés dominálja jelenleg az akadémiai gondolkodást.
} 
abban az értelemben, hogy nem ad útmutatókat arra nézve, hogy miként lehet az alkalmazottakat, a tanszékeket, a karokat, a szervezeti kultúrát és magát az egész intézményt „vállalkozóibbá” tenni (Fini et al. 2017).

Valószínűleg ezek a nehézségek is hozzájárultak ahhoz, hogy a vállalkozó egyetem modell még messze van attól, hogy az új globális formává váljon a szektorban. Ráadásul, a kutató egyetem koncepciója továbbra is tartja magát és mindeddig sikeresen ellenállt a trónfosztásnak (még ha a vállalkozói szemlélet egyes elemei meg is jelennek körükben is). A kutatás és a kutatói ösztöndíjak fontos elemei ennek a szervezeti felépítésnek, amely az akadémiai szabadság és önirányítás alapjain nyugszik (Marginson 2014). Ezek az elvek még manapság is komoly hatást gyakorolnak, hiszen az egyetemek egységesen a kutatási kiválóságot teszik meg fö törekvéseik egyikének, mind az akadémiai publikációk számát, mind a minőségét tekintve.

Ez azt is mutatja, hogy a kutatás nemcsak megtartotta a dominanciáját, de ha lehet, még meg is erősítette a pozícióját a fó egyetemi missziók között. Pillanatnyilag is erős státuszversengés zajlik az egyetemek között nemzeti és nemzetközi szinten egyaránt (Marginson 2014). Ebben a versenyben egy egyetem relatív helyezése nem az oktatási innovációktól vagy a hallgatók tanulási eredményeitől függ, hanem főként a kutatási kiválóságtól (azaz a publikációktól).

Ez a trend különösen nagy kihívást jelent az oktatásorientált felsőoktatási intézményeknek, amelyeknél a helyi és regionális igények kiszolgálása igen nagy hangsúlyt kap. Az egyik alkalmazkodási stratégia egyértelműen a homogenitás irányába mutat, amikor az oktatási misszió mellett/helyett a kutatás kerül az előtérbe, és a cél a kutató egyetemmé válás. Ennek a folyamatnak a feltételeit, nehézségeit és akadályait jól példázza Mtshali és Sooryamoorthy (2019) írása, amely bemutatja, hogy egy ilyen folyamatban olyan alkalmazottaknak kell felelős és produktív kutatókká válniuk, akik korábban fóként oktatási és mentor szerepben jelentek meg, valamint be kell vezetni egy kutatásfókuszú szervezeti kultúrát egy olyan intézményben, amelynek ez nem volt kiemelt küldetése. Mtshali és Sooryamoorthy (2019) kutatása arra mutat rá, hogy ez csak akkor lehet sikeres, ha alapvető intézményi újrastrukturálással jár együtt, amely kutatásorientált kultúra kialakulását és megerősödését támogatja. Ez azonban hosszú időt igénylő feladat.

Egy másik felsőoktatási szegmens, amely nem a két nagy modell valamelyikét követi, hanem saját utat próbál járni, az úgynevezett „alkalmazott tudományok egyeteme” szektor. Ezek az intézmények elsősorban oktatással foglalkoznak, szoros kapcsolatban a helyi munkaerőpiaccal. Ugyanakkor ennek a szektornak a stratégiája sem egyértelmű, itt is megjelenik az úgynevezett „akadémiai sodrás” (academic drift) jelensége (MorphewHuismann 2002; Schüll 2019). Ez pedig különösen nagy kihívás elé állítja ezt a szegmenst, hiszen valahogyan ezekre a konvergálást támogató igényekre is válaszolniuk kell ezeknek az intézményeknek úgy, hogy mindemellett fenntartsák és megtöltsék specifikus tartalommal az „alkalmazott tudományok egyeteme” jelleget.

Összességében, tehát ha a homogenitás és heterogenitás kérdését vizsgáljuk, azt láthatjuk, hogy két fö globális modell van, és mindkettő feltételezi a harmóniát és a szinergiát a fö oktatási missziók között. Ez a két modell erős példát állít az izomorf törekvéseknek, azaz az intézmények e két modell valamelyikéhez próbálják közelíteni 
szervezeti felépítésüket. Ugyanakkor ez a hasonulás értelmezhető egyfajta „családi hasonlóságként" is, wittgensteini értelemben ${ }^{5}$ azaz nem abban az értelemben, hogy minden felsőoktatási intézmény teljesen egyforma. Nem szabad ugyanis elfelejtkeznünk az olyan jelenségekről, mint az útfüggőség, a korábbi szervezeti formák hatása, vagy éppen az adott intézmény társadalmi-gazdasági környezete. Ezek mind-mind nagyban befolyásolják, hogy egy-egy ilyen globális modell hogyan és miként fordítható le a helyi környezetben - ha egyáltalán lefordítható (Göransson-Maharajb-Schmoch 2009).

Éppen ezért fontos kiemelni, hogy nincs univerzális megoldás a felsőoktatási intézmények számára, hanem a fejlődési terveiket és vízióikat hozzá kell igazítaniuk a saját lehetőségeikhez és az elérhető külső és belső forrásokhoz - ahogy azt Bazsa (2017) is kiemeli. Ennek egyik lehetséges útja lehet annak az újragondolása, hogy miként lehetnek az egyetemek társadalmilag és/vagy gazdaságilag jobban beágyazottak.

\section{IRODALOM}

Amsler, S. \& Facer, K. (2017) Contesting Anticipatory Regimes in Education: Exploring Alternative Educational Orientations to the Future. Futures, Vol. 94. pp. 6-14. https:// doi.org/10.1016/j.futures.2017.01.001.

Andessner, R. \& Greiling, D. (2017) University Funding in a Globalized World: A Step Back to the Roots? In: R. Andessner, D. Greiling \& R. Vogel (eds) Public Sector Management in a Globalized World. Wiesbaden, Springer Gabler. pp. 15-37.

Aoun, J. E. (2017) Robot-Proof. Higher Education in the Age of Artificial Intelligence. Cambridge (MA), MIT Press.

Arum, R. \& Roksa, J. (2011) Academically Adrift: Limited Learning on College Campuses. Chicago, University of Chicago Press.

Barnett, R. (2012) Learning for an Unknown Future. Higher Education Research E Development, Vol. 31. No. 1. pp. 65-77. https://doi.org/10.1080/07294360.2012.642841.

BAzsa Gy. (2017) Beszélgessünk a felsőoktatásról. Valóság, Vol. 60. No. 10. pp. 51-71.

Caplan, B. (2018) The Case Against Education: Why the Education System Is a Waste of Time and Money. Princeton (NJ), Princeton University Press.

Catrin-Groves, C. L. (2012) The Citizen Science Landscape: From Volunteers to Citizen Sensors and Beyond. International Journal of Zoology. http://dx.doi.org/ $10.1155 / 2012 / 349630$.

Clark, B. R. (1998) The Entrepreneurial University: Demand and Response. Tertiary Education and Management, Vol. 4. No. 1. pp. 5-16. https://doi.org/10.1007/BF02679392

Cribb, J. \& Sari, T. (2010) Open Science: Sharing Knowledge in the Global Century. Collingwood, Csiro Publishing.

Davidson, C. N. (2017) The New Education: How to Revolutionize the University to Prepare Students for a World in Flux. New York, Hachette.

Decuypere, M., Simons, M. \& Masschelein, J. (2011) ‘Perform, Measure Accurately, Optimise': On the Constitution of (Evidence-based) Education Policy. International Studies in Sociology of Education, Vol. 21. No. 2. pp. 115-135. https://doi.org/10.1080/ 09620214.2011 .575101$.

Ez arra utal, hogy lehetnek átfedő hasonlóságok intézmények között anélkül, hogy egyetlen meghatározó közös jellemző ott lenne mindegyikben. 
Docherty, T. (2011) For the University: Democracy and the Future of the Institution. New York - London, Bloomsbury.

Eтzкоwiтz, H. (1988) The Making of an Entrepreneurial University: The Traffic among MIT, Industry, and the Military, 1860-1960. In: E. Mendelsohn, M. R. Sмith \& P. Weingart (eds) Science, Technology and the Military. Dordrecht, Springer. pp. 515-540.

Etzkowitz, H., Webster, A., Gebhardt, C. \& Terra, B. R. C. (2000) The Future of the University and the University of the Future: Evolution of Ivory Tower to Entrepreneurial Paradigm. Research Policy, Vol. 29. No. 2. pp. 313-330. DOI: 10.1016/S00487333(99)00069-4.

Fecher, B. \& Friesike, S. (2014) Open Science: One Term, Five Schools of Thought. In: S. Bartling \& S. Friesike (eds) Opening Science. Cham, Springer. pp. 17-47.

Fini, R., Fu, K., Mathisen, M. T., Rasmussen, E. \& Wright, M. (2017) Institutional Determinants of University Spin-off Quantity and Quality: A Longitudinal, Multilevel, Cross-country Study. Small Business Economics, Vol. 48. No. 2. pp. 361-391. https://doi. org/10.1007/s11187-016-9779-9.

Fuller, T., Warren, L., Thelwall, S., Alamdar, F. \& Rae, D. (2010) Rethinking Business Models As Value Creating Systems. Leonardo, Vol. 43. No. 1. pp. 96-97. https:// doi.org/10.1162/leon.2010.43.1.96

Gee, J. P. (2013) The Anti-education Era: Creating Smarter Students through Digital Learning. New York, Palgrave-MacMillan.

Géring, Z., Király, G., Csillag, S., Kováts, G., Köves, A. \& Gáspár, T. (2018) Vision(s) of the University. Applying Participatory Backcasting to Study the Future of Higher Education. Journal of Futures Studies, Vol. 22. No. 4. pp. 61-82. https://doi.org/ 10.6531/JFS.201806.22(4).0005.

Göransson, B., Maharajh, R. \& Sснмосн, U. (2009) New Activities of Universities in Transfer and Extension: Multiple Requirements and Manifold Solutions. Science and Public Policy, Vol. 36. No. 2. pp. 157-164. https://doi.org/10.3152/030234209X406863.

Guerrero, M., Urbano, D., Fayolle, A., Klofsten, M. \& Mian, S. (2016) Entrepreneurial Universities: Emerging Models in the New Social and Economic Landscape. Small Business Economics, Vol. 47. No. 3. pp. 551-563. https://doi.org/10.1007/s11187016-9755-4.

Gumport, P. J. (2000) Academic Restructuring: Organizational Change and Institutional Imperatives. Higher Education, Vol. 39. No. 1. pp. 67-91. https://doi.org/ 10.1023/A:1003859026301

HammershøJ, L. H. (2019) The Perfect Storm Scenario for the University: Diagnosing Converging Tendencies in Higher Education. Futures, Vol. 111. No. 3. pp. 159-167. https://doi.org/10.1016/j.futures.2018.06.001.

Ibarra-Colado, E. (2007) Future University in Present Times: Autonomy, Governance and the Entrepreneurial University. Management Revue, Vol. 18. No. 2. pp. 117-137. https://doi.org/10.5771/0935-9915-2007-2-117.

Jeffries, P. R. \& Andrews, D. W. (2014) University Teaching 101. Coursera Online Course. https://www.coursera.org/course/univteaching101. [Letöltve 2014. 03. 22.]

Király G. (2019) A vállalkozó egyetem fogalmi tere. Elméleti keretek és gyakorlati kérdések. Közgazdasági Szemle, Vol. 67. No. 11. pp. 1187-1209. https://doi.org/10.18414/ KSZ.2019.11.1187.

Király, G. \& Géring, Zs. (2019) Introduction to ‘Futures of Higher Education' Special Issue. Futures, Vol. 111. No. 3. pp. 123-129. https://doi.org/10.1016/ j.futures.2019.03.004. 
KIRÁLY GÁBOR - GÉRING ZSUZSANNA: GAZDASÁGI, EGYÉNI ÉS TÁRSADALMI ÉRTÉKTEREMTÉS

Kosslyn, S. M., Nelson, B. \& Kerrey, B. (2017) Building the Intentional University: Minerva and the Future of Higher Education. Cambridge (MA), MIT Press.

Kováts G. (2011) Menedzserizmus-kritika az angol felsőoktatásban. Educatio, Vol. 20. No. 4. pp. 482-497.

Krueger, N. (2015) Thematic Paper on Entrepreneurial Education in Practice. Part 1: The Entrepreneurial Mindset. Paris, OECD-EC.

LACKéus, M. (2015) Entrepreneurship in Education: What, Why, When, How. Background Paper. Paris, OECD-EC.

Laredo, P. (2007) Revisiting the Third Mission of Universities: Toward a Renewed Categorization of University Activities? Higher Education Policy, Vol. 20. No. 4. pp. 441-456. https://doi.org/10.1057/palgrave.hep.8300169.

Leydesdorff, L. \& Etzkowitz, H. (1996) Emergence of a Triple Helix of UniversityIndustry-Government Relations. Science and Public Policy, Vol. 23. No. 5. pp. 279-286. https://doi.org/10.1093/spp/23.5.279.

Loi, M. \& Di Guardo, M. C. (2015) The Third Mission of Universities: An Investigation of the Espoused Values. Science and Public Policy, Vol. 42. No. 6. pp. 855-870. https:// doi.org/10.1093/scipol/scv012.

Marginson, S. (2014) University Research: The Social Contribution of University Research. In: J. C. Shin \& U. Teichler (eds) The Future of the Post-massified University at the Crossroads. Heidelberg, Springer. pp. 101-117.

Masschelein, J. \& Simons, M. (2015) Education in Times of Fast Learning: The Future of the School. Ethics and Education, Vol. 10. No. 1. pp. 84-95. https://doi.org/10.1080/ 17449642.2014 .998027$.

Morphew, C. C. \& Huisman, J. (2002) Using Institutional Theory to Reframe Research on Academic Drift. Higher Education in Europe, Vol. 27. No. 4. pp. 491-506. https:// doi.org/10.1080/0379772022000071977.

Mtshali, M. N. G. \& Sooryamoorthy, R. (2019) A Research-inducing Environment at a University of Technology in South Africa: Challenges and Future Prospects. Futures, Vol. 111. No. 3. pp. 194-204. https://doi.org/10.1016/j.futures.2018.06.017.

Ormrod, J. E. (2017) How We Think and Learn: Theoretical Perspectives and Practical Implications. Cambridge, Cambridge University Press.

Pinheiro, R., Langa, P. V. \& Pausits, A. (2015a) The Institutionalization of Universities' Third Mission: Introduction to the Special Issue. European Journal of Higher Education, Vol. 5. No. 3. pp. 227-232. https://doi.org/10.1080/21568235.2015.1044551.

Pinheiro, R., Langa, P. V. \& Pausits, A. (2015b) One and Two Equals Three? The Third Mission of Higher Education Institutions. European Journal of Higher Education, Vol. 5. No. 3. pp. 233-249. https://doi.org/10.1080/21568235.2015.1044552.

Pinheiro, R. \& Stensaker, B. (2014) Designing the Entrepreneurial University: The Interpretation of a Global Idea. Public Organization Review, Vol. 14. No. 4. pp. 497-516. https://doi.org/10.1007/s11115-013-0241-z.

Scharmer, C. O. \& Käufer, K. (2000) Universities as the Birthplace for the Entrepreneuring Human Being. Reflections: The SoL Journal on Knowledge, Learning and Change, 2000/1-19.

SchülL, E. (2019) Current Trends and Future Challenges of the Austrian Universities of Applied Sciences. Futures, Vol. 111. No. 3. pp. 130-147. https://doi.org/10.1016/ j.futures.2018.06.015.

Selingo, J. J. (2016) There Is Life after College: What Parents and Students Should Know about Navigating School to Prepare for the Jobs of Tomorrow. New York, HarperCollins. 
Selingo, J. (2018) The Future of Work and What It Means for Higher Education. http:// quantitative.emory.edu/documents/news-articles/article-Future-of-Work-Part-I.pdf [Letöltve: 2018. 11. 06.]

Shin, J. C. (2014a) The University as an Institution of Higher Learning: Evolution or Devolution? In: J. C. Shin \& U. Teichler (eds) The Future of the Post-massified University at the Crossroads. Heidelberg, Springer. pp. 13-27.

Shin, J. C. (2014b) University Teaching: Redesigning the University as an Institution of Teaching. In: J. C. Shin \& U. Teichler (eds) The Future of the Post-massified University at the Crossroads. Heidelberg, Springer. pp. 85-100.

Shin, J. C. \& Kiм, Y. (2014) Economic Crises and the Post-massification of Higher Education. In: J. C. Shin \& U. Teichler (eds) The Future of the Post-massified University at the Crossroads. Heidelberg, Springer. pp. 45-57.

Shore, C. (2010) Beyond the Multiversity: Neoliberalism and the Rise of the Schizophrenic University. Social Anthropology, Vol. 18. No. 1. pp. 5-29. https://doi.org/10.1111/ j.1469-8676.2009.00094.x.

Shumar, W. \& Robinson, S. (2018) Universities as Societal Drivers: Entrepreneurial Interventions for a Better Future. In: S. Bengtsen \& R. Barnett (eds) The Thinking University. Debating Higher Education: Philosophical Perspectives, Vol 1. Cham, Springer. pp. 31-45.

Simons, M. \& Masschelein, J. (2009) The Public and Its University: Beyond Learning for Civic Employability? European Educational Research Journal, Vol. 8. No. 2. pp. 204-217. https://doi.org/10.2304/eerj.2009.8.2.204.

Slaughter, S. \& Rhoades, G. (2004) Academic Capitalism and the New Economy: Markets, State, and Higher Education. Baltimore, Johns Hopkins University Press.

Wright, E. O. (2011) Real Utopias. Contexts, Vol. 10. No. 2.pp. 36-42. https://doi.org/ $10.1177 / 1536504211408884$.

A cikk a Creative Commons Attribution 4.0 International License (https://creativecommons.org/licenses/ by/4.0/) feltételei szerint publikált Open Access közlemény, melynek szellemében a cikk bármilyen médiumban szabadon felhasználható, megosztható és újraközölhető, feltéve, hogy az eredeti szerző és a közlés helye, illetve a CC License linkje és az esetlegesen végrehajtott módosítások feltüntetésre kerülnek. (SID_1) 